\title{
AMENDMENTS
}

\section{Author Correction: Engineered pegRNAs improve prime editing efficiency}

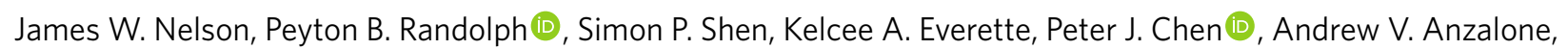
Meirui An (1), Gregory A. Newby (1D), Jonathan C. Chen, Alvin Hsu and David R. Liu (1)

Correction to: Nature Biotechnology https://doi.org/10.1038/s41587-021-01039-7, published online 4 October 2021.

The Supplementary Information file initially accompanying this article had a typographical error in the final oligonucleotide sequence shown in Supplementary Note 1 (specifically, CCC appeared as GGG) and the file has now been replaced.

The changes have been made to the online version of the article.

Published online: 8 December 2021

https://doi.org/10.1038/s41587-021-01175-0

(c) The Author(s), under exclusive licence to Springer Nature America, Inc. 2021

\section{Author Correction: Multiscale and integrative single-cell Hi-C analysis with Higashi}

Ruochi Zhang, Tianming Zhou and Jian Ma (D)

Correction to: Nature Biotechnology https://doi.org/10.1038/s41587-021-01034-y, published online 11 October 2021.

In the version of this article initially published, there were composition errors in the captions for Fig. 3b and Supplementary Fig. 15a,e,h. In each lettered caption, there were two sentences describing the number of genes having stable and dynamic single-cell compartment scores and their average transcription activity variability, respectively. The values in each caption were initially reversed for stable and dynamic compartment scores and variability. In Fig. 3b, in the corrected text now reading "There are 5,071 genes that have stable single-cell compartment scores, with average transcription activity variability equal to 77.4 . There are 5,075 genes that have dynamic single-cell compartment scores, with average transcription activity variability equal to 86.0," the values 5,071, 77.4 and 5,075, 86.0 replaced the original order of 5.075, 86.0 and 5,071, 77.4. The changes have been made to the online version of the article and the Supplementary information has been updated.

Open Access This article is licensed under a Creative Commons Attribution 4.0 International License, which permits use, sharing, adaptation, distribution and
reproduction in any medium or format, as long as you give appropriate credit to the original author(s) and the source, provide a link to the Creative Commons
license, and indicate if changes were made. The images or other third party material in this article are included in the article's Creative Commons license, unless
indicated otherwise in a credit line to the material. If material is not included in the article's Creative Commons license and your intended use is not permitted by statutory regula-
tion or exceeds the permitted use, you will need to obtain permission directly from the copyright holder. To view a copy of this license, visit http://creativecommons.org/licenses/
by/4.0/.

Published online: 3 March 2022

https://oi.org/10.1038/s41587-022-01263-9

(C) The Author(s) 2022 